УДК 341.96

DOI https://doi.org/10.32849/2663-5313/2019.11.64

\title{
Герман Галущенко,
}

канд. юрид. наук,

доцент кафедри міжнародного приватного права

Інституту міжнародних відносин

Київського начіонального університету імені Тараса Шевченка

\section{ВИБІР ІНОЗЕМНОГО ПРАВА МІЖНАРОДНИМ КОМЕРЦЙНИМ АРБІТРАЖНИМ СУДОМ ПРИ ТОРГОВО-ПРОМИСЛОВІЙ ПАЛАТІ УКРАЇНИ}

У статті досліджуються практичні аспекти вибору та застосування іноземного права арбітрами. Велика увага приділяється автором питанню вибору іноземного права арбітрами у випадках, коли сторони спору прямо не передбачили ией вибір у своєму договорі. У статті досліджується Регламент Міжнародного комериійного арбітражного суду при Торгово-промисловій палаті України у частині, що регулює питання вибору іноземного права. Окрім того, автор порівнює положення ивого Регламенту про вибір $і$ застосування іноземного права арбітражним трибуналом із регламентами інших міжнародних арбітражних інституиій, зокрема з Арбітражними правилами Міжнародної Торгової Палати, а також Правилами арбітражу та медіації Віденського міжнародного арбітражного иентру. Значну увагу автор приділяє аналізу справ, які розглядалися Міжнародним комериійним арбітражним судом при Торгово-промисловій палаті України, в яких сторони спору попередньо не зробили вибір права, яке застосовувалося б до суті спору, у своєму договорі, та відповідний обов'язок був покладений на арбітражний трибунал. Проаналізувавши доступні арбітражні рішення, автор дійшов висновку, що кількість справ, де перед арбітрами Міжнародного комериійного арбітражного суду при Торгово-промисловій палаті Украйни стояло б завдання визначити право, яке буде застосовуватися до суті спору, $\epsilon$ незначною. У статті звертається увага на спеиіальні закони, як-от Закон Украӥни «Про міжнародне приватне право» та «Про міжнародний комериійний арбітраж», які застосовує Міжнародний комериійний арбітражний суд при Торговопромисловій палаті України під час визначення застосовного права. Аналізуючи зазначені арбітражні справи, автор визначає, які фактори беруться арбітрами до уваги для визначення іноземного права. Так, серед іншого, автор виділяє такий фактор, як тісний зв'язок із правовідносинами, що найчастіше застосовується арбітрами для визначення права, яке буде застосовуватися до суті спору. Окрім того, автор аналізує випадки, коли правом, що застосовується до суті спору, є не окремі правопорядки, а міжнародні конвениії (Конвениія Організації Об'єднаних Націй про договори міжнародної купівліпродажу товарів 1980 року) ma lex mercatoria.

Ключові слова: міжнародне приватне право, міжнародний арбітраж, іноземне право, вибір права, lex mercatoria, міжнародний договір купівлі-продажу.

Постановка проблеми. Вибір та застосування іноземного права Міжнародним комерційним арбітражним судом при Торгово-промисловій палаті України у випадках, коли вибір права, що буде застосовуватися до суті спору, не був передбачений сторонами спору.

Аналіз останніх досліджень та публікацій. У вітчизняній науковій літературі станом натепер відсутні роботи, які були би присвячені питанню аналізу практики застосування іноземного права Міжнародним комерційним арбітражним судом при Торгово-промисловій палаті України. Водночас $\epsilon$ чимала кількість робіт, які загалом присвячені питанню застосування іноземного права міжнародним арбітражем, авторами яких є:
А.В. Асосков, В.О. Канашевський, С.В. НІколюкіна та ін.

Метою статті є дослідження практичних аспектів вибору та застосування іноземного права Міжнародним комерційним арбітражним судом при Торгово-промисловій палаті України.

Виклад основного матеріалу. Як відомо, основою правовідносин між сторонами є договір, частиною якого є арбітражне застереження. Саме тому усі положення договорів (якщо, звичайно, вони не суперечать публічному порядку) застосовуються до вирішення спорів. Коли виникає питання, яке право застосувати у зв'язку з виникненням спору, необхідно звернутися до змісту договору. 
Як правило, сторони договору передбачають вибір застосованого права, що $є$ основним моментом при формуванні арбітражу, якщо спір все ж виник. Лише якщо такий вибір сторін буде визнаний недійсним або не буде покривати усі правовідносини для того, щоб спір вирішився, арбітри можуть самостійно визначити матеріальне право, що буде застосовуватися до суті спору. Якщо арбітражний трибунал застосовує право, яке сторони не вибирали у своєму договорі та яке по суті суперечить фактичним положенням цього договору про вибір застосовного права, можна говорити про те, що арбітраж виходить за межі своїх повноважень, що може стати підставою для визнання майбутнього арбітражного рішення недійсним. Саме тому питання вибору та застосування іноземного права арбітражним трибуналом є непростим та актуальним практичним питанням.

Регламент Міжнародного комерційного арбітражного суду при Торгово-промисловій палаті України (далі - «МКАС при ТПП України») від 1 січня 2018 року передбачає, що арбітражний трибунал вирішує передані йому для вирішення спори відповідно до права, яке сторони вибрали для вирішення суті спору. Причому даний Регламент виключає відсилання до колізійних норм іноземного права та передбачає, що вибраним сторонами правом слід вважати лише матеріальне право тієї чи іншої країни. У разі, якщо сторони самостійно не зробили вибір застосованого права, арбітри будуть визначати це право на основі колізійних норм, які вони будуть вважати таким, які слід застосувати [8].

Схожі положення передбачаються в регламентах багатьох міжнародних арбітражних інституцій. Ідентичне формулювання міститься у новому Арбітражному регламенті Віденського міжнародного арбітражного центру (VIAC Arbitration Rules 2018). Так, стаття 27 цього Регламенту передбачає, що арбітри вирішують спір відповідно до права, вибраного сторонами, та будь-яке відсилання до іноземного права означає відсилання виключно до його матеріальних норм. У разі, коли сторони не вибрали право, арбітри будуть самостійно вирішувати, яке право слід застосувати у кожній окремій справі [2].

Ще одним схожим прикладом є стаття 21 Арбітражного регламенту Міжнародної торговельної палати, яка передбачає, що сторони самостійно вибирають право, що буде застосовуватися до суті спору, а в разі відсутності такого вибору арбітражний трибунал буде обирати застосовне право. [1]

Загалом на практиці МКАС при ТПП України нечасто застосовує пункт Регла- менту, за яким арбітражному трибуналу доводиться самостійно вибирати право, що буде застосовуватися до суті спору. Наприклад, за період 2006-2010 рр. арбітрам МКАС при ТПП України доводилося вирішувати питання про те, яке право слід застосовувати до суті спору, лише 4 рази.

Як приклад візьмемо справу від 27 грудня 2006 року, яка стосувалася спору між українською та китайською компаніями. Сторони, уклавши між собою договір купівлі-продажу, не вказали застосовне право. Після того, як сторони звернулися до МКАС при ТПП України щодо питання про право, яке підлягає застосуванню до суті спору, арбітражний трибунал взяв насамперед до уваги той факт, що як Україна, так і Китайська Народна Республіка є учасницями Конвенції $\mathrm{OOH}$ про міжнародні договори купівлі-продажу товарів. [5] Відповідно до пп. А) п. 1 ст. 1 цієї Конвенції, воно застосовується до договорів купівлі-продажу товарів між сторонами, комерційні підприємства яких перебувають у різних державах, коли ці держави є Договірними державами [6, ст. 61].

Наступною розглянемо справу від 2 липня 2009 року між українською та молдавською компаніями, в якій сторони також не передбачили вибір застосовного права. У цій справі, відповідно до статті 28 Закону України «Про міжнародний комерційний арбітраж» [4], арбітражний трибунал вважав доцільним застосувати колізійні норми України. Згідно 3 положеннями статті 44 Закону України «Про міжнародне приватне право» [3], правом, яке підлягає застосуванню до цього контракту, є матеріальне право України, яке було правом, що мало найбільш тісний зв'язок із правовідносинами, з яких виник спір. Право України було правом продавця за договором купівлі-продажу [6, ст. 337].

Аналогічним до цього було рішення МКАС при ТПП України про питання щодо вибору застосовуваного права у справі від 29 квітня 2010 року. Ця справа стосувалася спору між українською та білоруською компаніями, договір купівлі-продажу між якими не містив положень про вибір застосовуваного права. Згідно зі ст. 28 Закону України «Про міжнародний комерційний арбітраж», ст. 32 та 44 Закону України «Про міжнародне приватне право», а також беручи до уваги той факт, що відповідач (продавець) мав своє місцезнаходження на території України, арбітражний трибунал вирішив, що право України підлягає застосуванню до суті спору цієї справи. Водночас Україна є учасницею вже згаданої Конвенції ООН про міжнародні договори купівлі-продажу, яка в силу положень пп. b) п. 1 ст. 1 підлягає застосуванню 
до правовідносин сторін за контрактом міжнародної купівлі-продажу. Арбітражний трибунал, беручи до уваги п. 2 ст. 7 цієї Конвенції - питання, що стосуються предмета регулювання цієї Конвенції, які безпосередньо в ній не вирішені, підлягають вирішенню згідно із загальними принципами, на яких воно грунтується, а у разі відсутності останніх - згідно з правом, застосованим відповідно до норм міжнародного приватного права, вирішив застосувати право України у цьому випадку на субсидіарній основі [6, ст. 467].

Ще одним досить цікавим прикладом визначення права, що підлягає застосуванню до суті спору, арбітражним трибуналом МКАС при ТПП України є рішення у справі від 15 жовтня 2009, яка стосувалася спору між англійською та українською фірмами. Під час вирішення питання щодо права, що підлягає застосуванню, арбітражний трибунал взяв до уваги той факт, що позивач обгрунтовував свої позовні вимоги на основі норм матеріального права України, чим викликав заперечення збоку відповідача, оскільки останній зазначав, що питання вибору права не узгоджувалося сторонами у договорі. Тим не менше водночас відповідач обгрунтовував свої заперечення на вимоги, заявлені позивачем, також на основі матеріального права України. У цій справі арбітражний трибунал звернувся до положень п. 5 ст. 5 Закону України «Про міжнародне приватне право», відповідно до якого вибір застосовуваного права сторонами або зміна раніше вибраного права, які зроблені після вчинення правочину, мають зворотну дію і $є$ дійсними з моменту вчинення правочину. Таким чином, беручи до уваги вибір права, який сторони здійснили вже на стадії вирішення спору в МКАС при ТПП України, а також положення ст. 28 Закону України «Про міжнародний комерційний арбітраж», ст. 5 та 43 Закону України «Про міжнародне приватне право», положення п. 1 ст. 14 Регламенту МКАС при ТПП України, арбітражний трибунал вирішив, що правом, що підлягає застосуванню в цій справі, є матеріальне право України [6, ст. 378].

Що стосується широкого застосування lex mercatoria в ході арбітражного процесу в Україні як сторонами процесу, так і арбітражним трибуналом, то тут навряд чи можна говорити про позитивні результати. Варто сказати, що, відповідно до законодавства України, застосування lex mercatoria можливе лише за умови прямої вказівки на це у зовнішньоторговельному контракті або ж (але вкрай рідко) у разі відсутності застосованого права сторонами та неможливості відшукання арбітрами належної колізійної норми.

Прикладом того, що lex mercatoria все ж може застосовуватися в міжнародному арбітражному процесі в Україні є справа, подана на розгляд у МКАС при ТПП України 6 червня 2007 року. Справа стосувалася спору між українською та чеською компаніями. В арбітражному застереженні сторони передбачили, що правом, яке регулює зовнішньоекономічний контракт, $є$ міжнародне торговельне право. У силу того, що обидві держави учасниць цих правовідносин, з яких виникнув спір, є сторонами Конвенції $\mathrm{OOH} \mathrm{про} \mathrm{міжнародні} \mathrm{договори} \mathrm{купівлі-}$ продажу товарів, на основі положень пп. а) п. 1 ст. 1 цієї Конвенції до договорів купівлі-продажу товарів між сторонами, комерційні підприємства яких перебувають у різних державах, коли ці держави є договірними державами, - Конвенція ООН про міжнародні договори купівлі-продажу товарів була визначена як така, що підлягає застосуванню до правовідносин сторін контракту [6, ст. 164].

\section{Висновки}

Отже, Регламент Міжнародного комерційного арбітражного суду при Торговопромисловій палаті України прямо передбачає, що арбітражний трибунал може взяти на себе повноваження щодо вибору права, що буде застосовуватися до суті спору, якщо сторони попередньо не передбачили цей вибір. Окрім того, застосування вибраного права має певні обмеження для арбітрів, які проявляються в тому, що застосування означає застосування виключно матеріальних норм іноземного права, а не колізійного. Попри можливість вибирати право у певних випадках, арбітри Міжнародного комерційного арбітражного суду при Торгово-промисловій палаті України вкрай рідко це роблять, оскільки сторони, як правило, все ж самостійно здійснюють вибір права. Що стосується факторів впливу на вибір того чи іншого права арбітрами, то варто сказати, що вони застосовують традиційні колізійні прив'язки (наприклад, право місця знаходження продавця). Також арбітри беруть до уваги той факт, чи $є$ країни сторонами міжнародних договорів. Так, досить часто арбітри обирають Конвенцію ООН про міжнародні договори купівлі-продажу як право, що буде застосовуватися до суті спору. 


\section{Список використаних джерел:}

1. ICC Rules of Arbitration 2018. URL: https:/ iccwbo.org/dispute-resolution-services/arbitration/ rules-of-arbitration/ (дата звернення: 03.09.2019).

2. Rules of arbitration and mediation of the Vienna International Arbitral Center of 2018. URL : https://www.viac.eu/en/arbitration/ content/vienna-rules-2018-online\#ApplicableLawA miableCompositeur (дата звернення: 03.09.2019).

3. Про міжнародне приватне право : Закон України від 23.06.2005 № 2709-IV. URL : https:// zakon.rada.gov.ua/laws/show/2709-15 (дата звернення: 03.09.2019).

4. Про міжнародний комерційний арбітраж : Закон України від 24.02.1994. № 4002-XII. URL : https://zakon.rada.gov.ua/laws/ show/4002-12 (дата звернення: 03.09.2019).

5. Конвенція Організації Об'єднаних Націй про договори міжнародної купівлі-продажу това- рів від 11 квітня 1980 року. URL : https://zakon. rada.gov.ua/laws/show/995 003 (дата звернення: 03.09.2019).

6. Практика Международного коммерческого арбитражного суда при ТПП Украины по рассмотрению внешнеэкономических споров за 2006-2010 годы / под общей ред. Н.Ф. Селивона. Київ, 2013. 535 с.

7. Практика Международного коммерческого арбитражного суда при ТПП Украины по рассмотрению внешнеэкономических споров за 2006-2010 годы / под общей ред. Н.Ф. Селивона. Київ, 2013. 535 с.

8. Регламент Міжнародного комерційного арбітражного суду про Торгово-промисловій палаті України від 1 січня 2018 року. URL : https://icac.org.ua/wp-content/uploads/ReglamentISAS-pry-TPP-Ukrayiny.pdf (дата звернення: 03.09.2019).

The article studies practical aspects of choice and application of foreign law by arbitrators. The author pays attention to the question of the choice of foreign law by arbitrators in cases where the parties to the dispute have not explicitly provided for this choice in their contract. The article examines the Rules of the International Commercial Arbitration Court at the Chamber of Commerce and Industry of Ukraine in the part that regulates choice of foreign law. In addition, the author compares the provisions of these Rules on selection and application of foreign law by the arbitral tribunal with the rules of other international arbitral institutions, in particular, with the Arbitration Rules of the International Chamber of Commerce, as well as the Arbitration and Mediation Rules of the Vienna International Arbitration Center. The author pays considerable attention to the analysis of cases dealt with by the International Commercial Arbitration Court at the Chamber of Commerce and Industry of Ukraine, in which the parties to the dispute had not previously made choice of the law applicable to the substance of the dispute in their contract and the respective duty was assigned to the arbitration tribunal. Analyzing the available arbitral awards, the author concluded that the number of cases before the arbitrators of the International Commercial Arbitration Court at the Chamber of Commerce and Industry of Ukraine assigned with determining the law applicable to the merits of the dispute is insignificant. The author also pays attention to the special laws, such as the Law of Ukraine "On private international law" and the Law "On international commercial arbitration" applied by the International Commercial Arbitration Court at the Chamber of Commerce and Industry of Ukraine while determining the applicable law. Analyzing these arbitration cases, the author determines the factors, taken into account by arbitrators in order to determine the foreign law. Among others, the author distinguishes characteristic performance as the factor commonly used by arbitrators for determination of applicable law. In addition, the author analyzes the cases where the law applicable to the substance of the dispute is not a domestic law but international conventions (Convention on the International Sale of Goods) and lex mercatoria.

Key words: private international law, international arbitration, foreign law, choice of law, lex mercatoria, international sales contract. 